\title{
原子力発電給水流量計校正のための高レイノルズ数実流校正設備* (設備の概要および特性)
}

\author{
古 市 紀 之*1, 佐 藤 浩 志*1 \\ 寺尾吉 哉*1, 高 本 正 樹*1
}

\author{
High Reynolds Number Facility for Calibration of Feedwater \\ Flowmeter in Nuclear Power Plant \\ (Overview and Characteristic of Facility)
}

\author{
Noriyuki FURUICHI ${ }^{* 2}$, Hiroshi SATO, \\ Yoshiya TERAO and Masaki TAKAMOTO
}

\author{
${ }^{* 2}$ National Institute of Advanced Industrial Science and Technology, \\ National Metrology Institute of Japan Liquid Flow Standards Section, \\ Fluid Flow Division AIST Tsukuba Central 3, 1-1-1 Umezono, Tsukuba-shi, Ibaraki, 305-8563 Japan
}

\begin{abstract}
Since 1990s, an uprate of the thermal output has been carried out in USA using a method of measurement uncertainty recapture called as MUR. The principle of the MUR method is based on reduction of the measurement uncertainty of the feedwater flow rate using an ultrasonic flowmeter with high accuracy. Since the measurement uncertainty of thermal output can be reduced using that flowmeter, the thermal output can be increased within the reducing value of the uncertainty. The ultrasonic flowmeter using in a feedwater loop should be calibrated under the same condition of a nuclear power plant because of the correction factor of it is strongly affected by the condition of the flow field such as Reynolds number. To realize an actual flow calibration of feedwater flowmeter used at nuclear power stations at Reynolds numbers of up to 18 million, a new test facility is constructed at National Metrology Institute of Japan (NMIJ). This very large Reynolds number is achieved at a flow rate of $12000 \mathrm{~m}^{3} / \mathrm{h}$ and water temperature of $70^{\circ} \mathrm{C}$ in a $600 \mathrm{~mm}$ pipe. Then the pipe prover system for $750 \mathrm{~m}^{3} / \mathrm{h}$ is also constructed to confirm of the temperature effect on the flowmeters. This paper describes overview and characteristic of the new facility.
\end{abstract}

Key Words : Actual Flow Calibration, Flowmeter, High Reynolds Number, Nuclear Power Generation, Pipe Flow

\section{1. 腥言}

原子力発電所における増出力方法として, MUR (Measurement uncertainty recapture) と呼ばれる手法が 1990 年代よりアメリカにおいて行われてきている(1)(2). 現在の原子力発電における熱出力の不確かさは BWR も PWR も一律 $2 \%$ と見込まれており(3)，これは米 10CFR50 の Appendix $\mathrm{K}^{(4)}$ に基づく, ECCS 解析の限界 值とされる. したがって原子炉においては, 計測の不 確かさを踏まえて, 定格出力の $102 \%$ 熱出力の上限 と考えられている. ここで, 図 1 に示すように, この 熱出力の計測の不確かさを減じることができれば, 法 体系の更新を行うことなく増出力を行うことができる というのが，MUR の基本概念である.この手法はコ スト面からもメリットが大きく, 日本の原子力発電所 においても導入が検討されはじめている(5).

* 原稿受付 2007 年 7 月 30 日.

*1 正員, 産業技術総合研究所 ( 305-8563 つくば市梅園 1-1-1 中央第三).

E-mail : furuichi.noriyuki@aist.go.jp
BWR の場合, 熱出力は原子炬入口での給水と出口 での蒸気の持つエンタルピの差として算出される. そ のため, 前述の熱出力の不礁かさ $2 \%$ $\%$ 万, 1.76\%が 給水流量の計測の不確かさとして見込まれている. こ の給水流量計測は, 従来はフローノズルと呼ばれる差 圧式の流量計を用いて行われてきており，1.76\%とい う不確かさは 1976 年に GE 社より発行された $\mathrm{GETAB}^{(\text {() }}$ という解析コードに基づいたものである.

MUR は, 現在使用されている流量計に対し, これら よりも不確かさが小さく見積もられている超音波流量

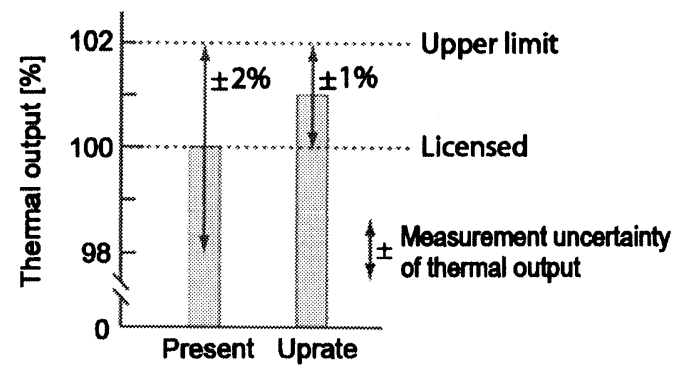

Fig.1 A concept of uprate by MUR method 
計を用いて行おうとするものである. したがって, 設 備の大幅な更新も必要なく, 流量計の新規の導入のみ によって増出力が可能であると言える. このように非 常に簡便かつコストメリットも大きい手法であるが, 問題点が二つ上げられる. 流量計の実流校正とトレー サビリティである.

流量計の実流校正については, 流量計の専門家の統 一的見解として, 取り付けられた流量計の精度が安全 上重要であるのであれば, その流量計は設置される配 管内流れと同等のレイノルズ数において実流校正が必 須であると考えられている. しかしながら，例えば福 島第二発電所の給水配管では, $3000 \mathrm{t} / \mathrm{h}$ の流量かつその

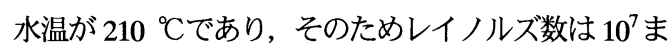
で達する. このように高いレイノルズ数において流量 計を校正する設備は世界に存在しないため, 従来のフ ローノズルに関しては, その流出係数を外挿によって

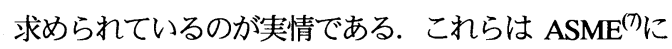
基づいて製作されており, ここで外挿を許しているこ とに起因する. なお, この ASMEには精度の担保とし てのトレーサビリティや不確かさのバジェットに関し ての記述はない.これは $\mathrm{GUM}^{(8)}$ のよう不確かさの概 念が確立される前の指針であるからであると言える. 一方, 超音波流量計は特に補正係数が流速分布に強く 依存するため, ISO ${ }^{(9)}$ では，超音波流量計の実流校正 を必須としており, もし 70\%程度までの実流校正試験 ができないのであれば流量計の不確かさに $0.15 \%$, 40\%であれば0.3\%加えることとしている.

計測機器のトレーサビリティの重要性については, 給水流量計も例外ではない. 国家標準からのトレーサ ビリティを確保し, 設置する流量計の不確かさを明確 にすることは，その性能の出展を明確にするだけでは なく, 安全確保のためにも重要である. 上記のように 外挿によって求められた流出係数は, その外挿の元に なるデータがトレーサビリティを確保していても，そ れを確保できているとは言えない.

そこで産業技術総合研究所・計測標準総合センター （NMIJ : National Metrology Institute of Japan）では，原 子力発電所の給水配管をレイノルズ数の観点から模擬 できる実流校正設備を構築してきた ${ }^{(10)(11)}$. 本設備は 600A 配管において, $10^{7}$ オーダーのレイノルズ数にお ける流量計校正を可能にしており，このような設備は 世界的に例を見ない，また，従来から存在する液体流 量の国家標準設備を拡張することにより構築された設 備であることから, トレーサビリティが確保されてい る. したがって, この設備において校正された流量計 は，国家標準にトレーサブルであるといえる，そのた
め給水流量計のみならず, 高レイノルズ数における流 量計校正の観点から, 非常に広範囲な目的に使用され うる. 本報告では, 設備を詳細に報告した後, 設備の 性能評価についても報告するものとする.

\section{2. 記号}

\begin{tabular}{|c|c|}
\hline$I$ & : パルス数 \\
\hline$K$ & : K ファクター $[\mathrm{Pulse} / \mathrm{L}]$ \\
\hline$M$ & : 秤量タンクにおける水の質量 $[\mathrm{kg}]$ \\
\hline$n$ & : 校正の繰り返し数 \\
\hline$Q$ & : 流量 $\left[\mathrm{m}^{3} / \mathrm{h}\right]$ \\
\hline$t$ & $\begin{array}{l}\text { : 秤量タンクにおいてダイバータがタンク } \\
\text { 側に切替わっている時間, または循環運転 } \\
\text { における計測時間 }[\mathrm{s}]\end{array}$ \\
\hline$T$ & : 温度 $\left[{ }^{\circ} \mathrm{C}\right]$ \\
\hline$U$ & : 校正の拡張不確かさ \\
\hline$V$ & : 管内流速 [m/s] \\
\hline$V s$ & : 基準体積 $\left[\mathrm{m}^{3}\right]$ \\
\hline$\rho$ & : 密度 $\left[\mathrm{kg} / \mathrm{m}^{3}\right]$ \\
\hline$\sigma$ & : 標淮偏差 \\
\hline 添え字 & \\
\hline $\mathrm{A} \sim \mathrm{D}$ & : A〜D の各ラインにおける值 \\
\hline DUT & : 被試験流量計における值 \\
\hline WT & : 秤量タンクにおける値 \\
\hline a & : 空気の值 \\
\hline b & : バルクの值 \\
\hline f & : 計測開始後の值 \\
\hline i & : 計測開始前の值 \\
\hline $\mathrm{rms}$ & : rms 值 \\
\hline w & : 水の值 \\
\hline $\mathrm{z}$ & : 流れ方向座標 \\
\hline
\end{tabular}

\section{3. 高レイノルス数実流校正設備概要}

3.1 設備概钼 図 2 に設備の全体像を示す. 本校正 設備は, NMIJ に既存の液体流量（水）に関する国家 標準設備を拡張したものである. 図中のオーバーフロ 一ヘッドタンクと $50 \mathrm{t}$ 秤量タンクが既設である. 従来 は $400 \mathrm{~A}$ 配管において $3000 \mathrm{~m}^{3} / \mathrm{h}$ を最大としており,そ のためレイノルズ数は $10^{6}$ 程度であった. この設備を 拡張する形で循環ループを構築した. この循環ループ はヘッダー, 循環ポンプ4台（330 kW）およびそれに 付随したライン (以下 A D ライン) , 各ラインに設 置された実用参照標準流量計（以下 WS）試験部, 戻 り管, プルーバー等によって構成されている.

本設備を使用した校正は, 基本的にWS の流量を標 準とする比較法により行われる. WS は図のようにポ 


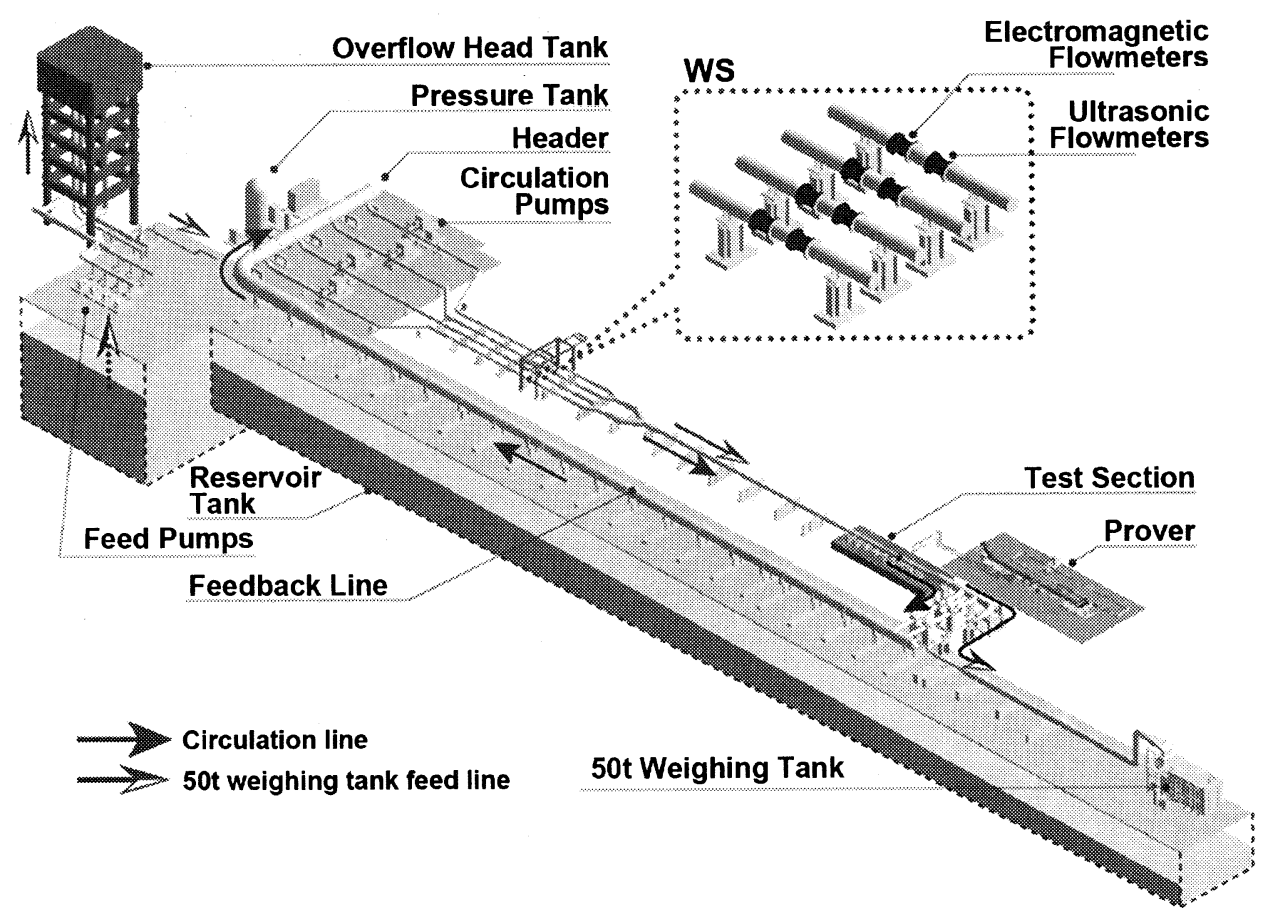

Fig.2 Overview of high Reynolds number facility

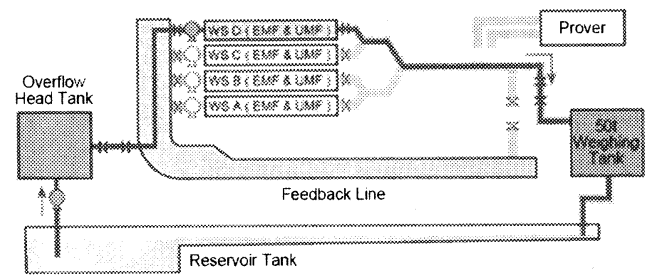

Fig.3 Schematic diagram of feedwater mode

ンプ下流側に設置されている. WS およびWS 設置位 置の配管は 400A となっており, 上流側には管内径の 20 倍の直管長さが取られている. また, 10 倍上流の位 置には整流板を設置した，なお，温度および圧力は WS すぐ下流において，ライン毎に測定される. WS は, 原理の異なる流量計 2 台からなる. 上流側から順 に電磁流量計 (以下 EMF) , 超音波流量計 (以下 UFM) となっている. 電磁流量計は Krohne 社製 OPTIFLUX であり, 超音波流量計については同社製 ALTOSONIC $\mathrm{V}$ を使用している. 特にUFM については, 5 本の測定 線を持つものであり, 精度および繰り返し性について は, 非常に高いスペックを持つ.

WS の下流側において，それぞれのラインからの配 管が合流する. 合流後の配管は $600 \mathrm{~A}$ となっており, これより管内径の約 60 倍の直管長さを取ることがで
きる. この直管部は, $200 \mathrm{~A}$ 程度から $600 \mathrm{~A}$ 程度の配管 に対応することができる．試験部は合流部より管内径 の 50 倍下流（600A配管の場合）としており，この位 置に被試験流量計（以下DUT）を設置する. 試験部の 下流側にも温度計, 圧力計を設置した. なお, 試験部 についてのタ, 屋内設備となっている.

試験部より下流側において, 送水経路は $50 t$ 秤量夕 ンクへのラインと戻り管への配管に分岐する. 分岐後, それぞれに流量調節弁および遮蔽用のバルブが 2 台設 置されている.これはリークチェックのためである.

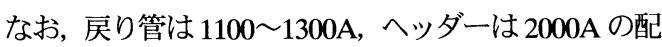
管となっている. また, プルーバーは, この循環ルー プからは独立して設置されている.

3.2 送水運転試験 本設備では, オーバーフローヘ ッドタンクおよび $50 \mathrm{t}$ 秤量タンクを使用した送水試験 を行うことができる. この 50t 秤量タンクについては 日本における流量の国家標準となっていることから， これを使用して校正された流量計または流量校正設備 は, トレーサビリティを持つことを意味する.

送水運転時の送水経路を図 3 に示した. オーバーフ ローヘッドタンクからヘッダーを通過, 各ラインから 


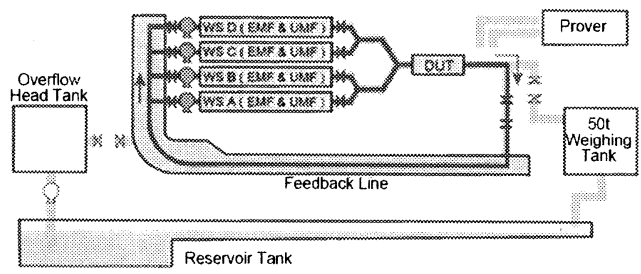

Fig.4 Schematic diagram of circulation mode

試験部を通過し, 50t 秤量タンクへ流入する.この際, 戻り管への配管はダブルバルブにより遮蔽されており, バルブからのリークチェックを行うことができるよう になっている.

流量は最大 $3000 \mathrm{~m}^{3} / \mathrm{h}$ までであり, 基本的にはひと つのラインからの送水となる. 系全体の圧力はヘッド 圧によりおよそ $0.2 \mathrm{MPa}$, また, 循環ポンプの吐出圧 より, 試験部ではおよそ $0.5 \mathrm{MPa}$ となる. 水温に関し ては $30^{\circ} \mathrm{C}$ までの試験を行うことができる.

この送水運転による試験は, 主にWS の校正を目的 とする. 下記は A ラインの WS を校正した時の K フ アクター算出式である.

$$
K_{\mathrm{A}}=\frac{I_{\mathrm{A}} \cdot \rho_{\mathrm{w}}\left(T_{\mathrm{A}}\right)}{1000 \cdot t_{\mathrm{A}}} \cdot \frac{t_{\mathrm{wT}} \cdot\left(1-\rho_{\mathrm{a}} / \rho_{\mathrm{w}}\left(T_{\mathrm{WT}}\right)\right)}{\left(M_{\mathrm{f}}-M_{\mathrm{i}}\right)}
$$

なお，本校正は ISO17025 に準拠して行われるもので ある. この試験において校正された WS は, 配管から 取り外されることなく以下の循環による試験に用いら れる. 一般に, 流量計の取り外しが行われる場合には 不確かさが增大するが, 本設備ではそれが不必要であ り, 結果として設備の不確かさを小さくすることが可 能となっている.

3.3 循環運転試験 循環運転モードの送水経路を図 4 に示す. 循環運転では, 平行に並んだ 4 台の循環ポ ンプにより流れを発生させる. ポンプ1台あたりの最 大流量は $3000 \mathrm{~m}^{3} / \mathrm{h}$ であり, 各ラインの合流後の最大 流量は $12000 \mathrm{~m}^{3} / \mathrm{h}$ となる.

この循噮運転時は膨張タンクにより, 系の圧力が送 水運転時同様 $0.2 \mathrm{MPa}$ に保たれている. ポンプの吐出 圧から, WS 近辺における圧力はおよそ $0.6 \mathrm{MPa}$, 試験 部ではおよそ $0.5 \mathrm{MPa}$ となる. なお, 運転時の圧力変 動は小さいことを確認している（ $\pm 0.01 \mathrm{MPa}$ 以下） .

水温は, 常温から $70{ }^{\circ} \mathrm{C}$ における試験を可能として いる. 水温の制御は地下貯水槽の水を低熱源とした熱 交換によって行われ, 高温時の試験温度は $70 \pm 2{ }^{\circ} \mathrm{C}$ の 範囲で制御が可能であるが，1 試験サイクルを 1 時間
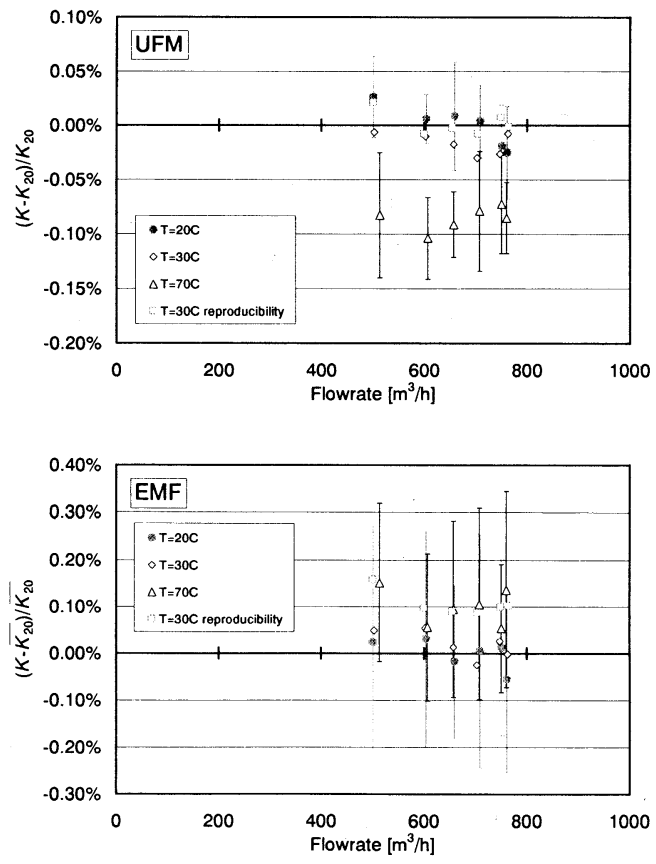

Fig.5 Temperature dependence of same type flowmeter of WS

程度とした場合, $\pm 0.2^{\circ} \mathrm{C}$ 程度で運転が可能となってい る. なお, 水温が $70{ }^{\circ} \mathrm{C}$, 流量 $12000 \mathrm{~m}^{3} / \mathrm{h}$ の条件のも と, 600A 配管（スケジュール 20S）では, 最大レイ) ルズ数 $1.8 \times 10^{7}$ を達成することができる.

DUT の校正は, この循環運転により行われ，WS と の比較法により, 下記の式により $\mathrm{K}$ ファクターが算出 される.

$$
\begin{aligned}
& Q_{\mathrm{DUT}}=\frac{1}{t}\left(\frac{I_{\mathrm{A}}}{K_{\mathrm{A}}}+\frac{I_{\mathrm{B}}}{K_{\mathrm{B}}}+\frac{I_{\mathrm{C}}}{K_{\mathrm{C}}}+\frac{I_{\mathrm{D}}}{K_{\mathrm{D}}}\right) \\
& K_{\mathrm{DUT}}=\frac{I_{\mathrm{DUT}}}{Q_{\mathrm{DUT}}}
\end{aligned}
$$

ここで, WS の K ファクターは試験時の水温に影響を 受ける. したがって, 常温時は 3.2 節において得られ た值を使用するが, 高温時は別途, 值を算出する必要

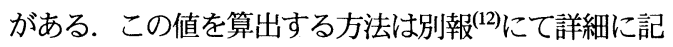
述する.

3.4 プルーバー設備および試験 一般的に流量計 は温度特性を持ち, 水温により $\mathrm{K}$ ファクターが変化す る. 図 5 に本設備のWS と同じタイプの流量計（ただ し口径は 200A)の水温を変化させた場合の校正結果を 示す.この結果はスウエーデン SP において校正され た結果である. 縦軸は, $20^{\circ} \mathrm{C}$ における平均値により正 


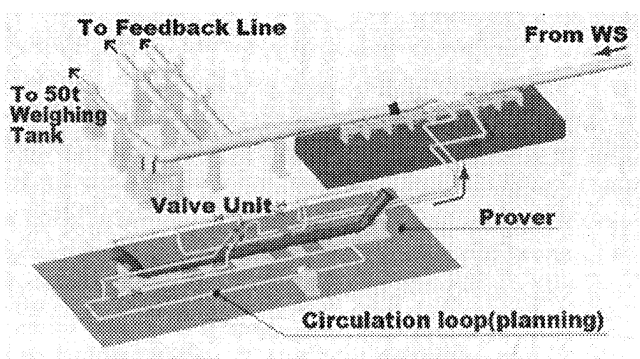

Fig.6 Detail of Prover system

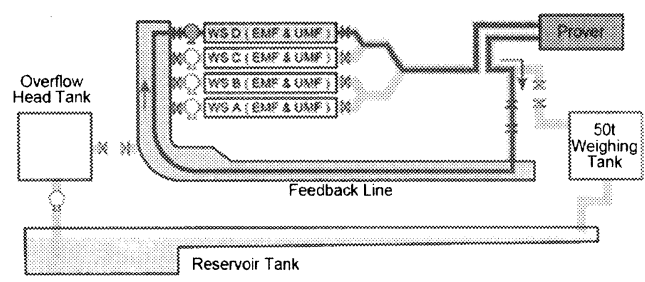

Fig.7 Schematic diagram of calibration by Prover

規化している. また，エラーバーは $2 \sigma （ \sigma:$ 繰返し測 定の標準偏差）を意味する.

UFM の場合は, 明瞭な温度依存性が観測されており, 温度が高くなるほどKファクターが小さくなる傾向に ある. しかしながら, EMFについてはその逆で, 温度 が高くなるほどKファクターが大きくなる傾向にある. また, EMFについては $30^{\circ} \mathrm{C}$ の再現性試験の結果は良 好とは言えないが, これは $30^{\circ} \mathrm{C}$ から $70^{\circ} \mathrm{C}$ へ昇温する のに必要とした時間 (12 時間程度) と, $70^{\circ} \mathrm{C}$ から $30^{\circ} \mathrm{C}$ へ水温変更する時間（水の入れ替え時間として 3 時間 程度）から，水温変化に対して十分な慣らし時間を持 たなかったことに起因していると考えられる. 本試験 では行っていないが, 流量計の配管材の膨張係数によ る補正がよく行われる. しかしながら，この補正だけ では十分に温度変化に関する特性を知ることは難しく, また流量計によってもその特性が異なることが，これ らの結果から分かる.

以上のことから，WS についても実際の温度特性に ついて確実に求める必要があるため, 流量計の校正設 備として一般的なプルーバー（図 6）を設置した. プ ルーバーは, 秤量タンクのように系を大気に開放する ことなく運転することができるため, 高圧・高温条件 下における流量計の校正を行うことができる. プルー バーは全長約 $20 \mathrm{~m}$ で, 基準体積が約 $2 \mathrm{~m}^{3}$, 最大流量 は $750 \mathrm{~m}^{3} / \mathrm{h}$ の設定となっている. なお, ディテク夕間 隔は最大流量時に約 $10 \mathrm{~s}$ となる,
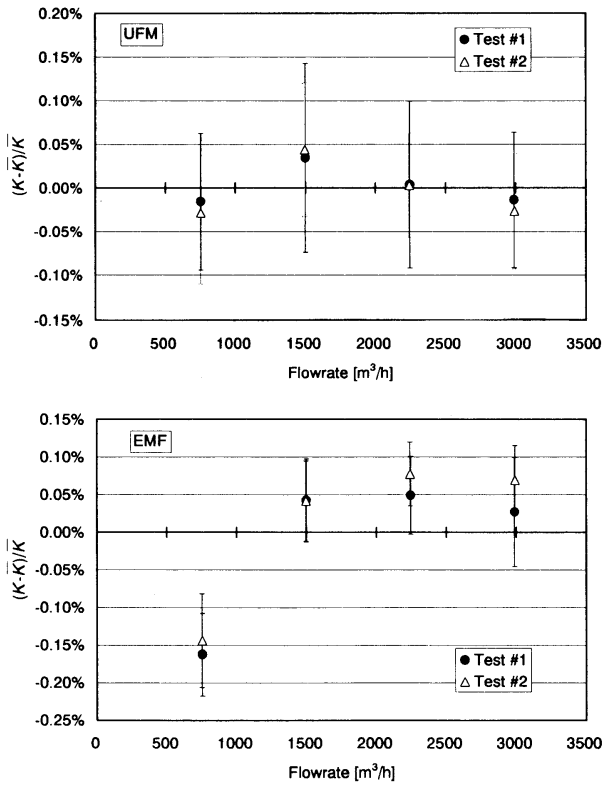

Fig.8 A characteristic of WS of B-line

プルーバーの試験時における送水経路を図 7 に示す. このプルーバーは通常は循環ループには接続されてい ない. 校正試験を行う場合のみ, DUT 設置位置より下 流側に連絡配管を設置し, 通水させるものとしている.

\section{4. 設備性能試㰸}

4.1 WS 特性(常温) 各ラインの WS の校正結果の うち, 代表的な結果として B ラインの校正結果を図 8 に示す. エラーバーは $2 \sigma$ ( $\sigma:$ 連続した $n$ 回の測定の 標㔼偏差）を意味し, Test \#1 とTest \#2 は, 異なった 日に行われた測定結果を示す. 本設備における WS の 連続した試験における繰り返し性は非常に良く, UFM については標準偏差で $0.02 \%$ 程度, また, EMFについ ても $0.015 \%$ 程度である. 日を変えた再現性 (日間変動) についても良好で, 分散分析では, 試験結果のばらつ きから分離することができない.

本結果にも明瞭に現れているが, 流量計の特性は流 量またはレイノルズ数に強く依存する, 低流量の結果 からの外挿は必ずしも実態を反映できるものではない， 本結果からも流量計の実流校正が不可欠であることが 分かる.

次に, 秤量タンク法と比較法（送水運転試験と循環 運転試験）の校正結果の妥当性を検討する. 図 4 中の DUT の位置に, WS と同タイプの流量計（ただし口径 は600A）を設置し, この流量計を秤量タンク法および 比較法による校正を行い, それぞれから K ファクター 


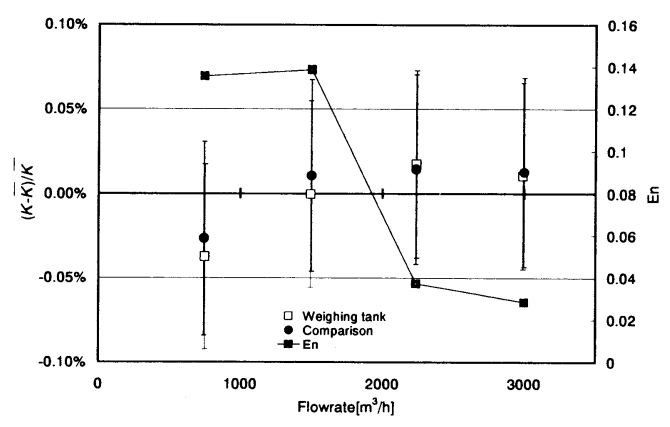

Fig.9 Comparison between weighing tank and comparison method

を算出した. B ラインから送水した場合の結果を図 9 に示す. それぞれの手法による校正結果はほぼ一致し ていることが分かる. 眓中 En 值は, 下記の式から算 出される.

$$
\mathrm{En}=\frac{\left|K_{\mathrm{w}}-K_{\mathrm{c}}\right|}{\sqrt{{U_{\mathrm{WT}}}^{2}+U_{\mathrm{CM}}{ }^{2}}}
$$

ここで, 校正の拡張不確かさ $U_{\mathrm{WT}}$ (秤量夕ンク法) お よび $U_{\mathrm{CM}}$ （比較法）は以下のように算出する.

$$
U=2 \times \sqrt{u_{\mathrm{CMC}}^{2}+\frac{\sigma^{2}}{n}}
$$

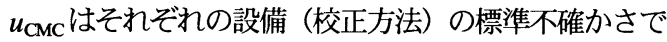
あり, 秤量タンク法では $0.027 \%$, 比較法では $0.028 \%^{(12)}$ である. En 值は一般的に, 1 以下であればそ れぞれの結果が拡張不確かさの範囲で一致しているこ とを意味する指標であるが，本設備では B ライン以外 からの送水も含めて, 測定流量範囲で 0.3 以下であっ た. 以上のことから, 本設備におけるWS および，こ れを用いた比較法による校正が適正に行われることが 示された.

4.2 流速分布および乱れ強さ分布 試験部において, 偏流や旋回流が存在するような場合は, 流量計の校正 精度に著しく影響をおよぼす可能性がある. 本設備で は被試験流量計まで管内径の 50 倍の直管長さを確保 しており, 発達した流れとするには十分な長さと考え られるが, 校正流量点によっては, 合流部において A・ $\mathrm{B}$ 側と $\mathrm{C} \cdot \mathrm{D}$ 側からの流量が均等にならない. 例えば, 流量 $9000 \mathrm{~m}^{3} / \mathrm{h}$ にて試験を行う場合は, $\mathrm{A} \cdot \mathrm{B} \cdot \mathrm{C}$ の各ラ インから $3000 \mathrm{~m}^{3} / \mathrm{h}$ 流し, D ラインからは送水しない. また，単一のラインからの送水も想定され，偏流や旋 回流の発生の可能性を否定できない. そのため, 試験

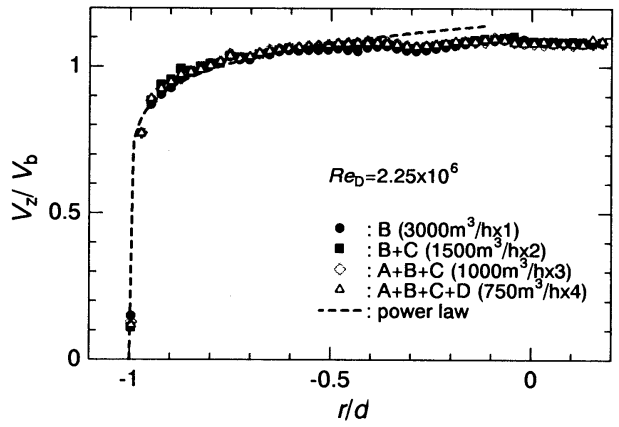

Fig.10 Velocity profile at test section

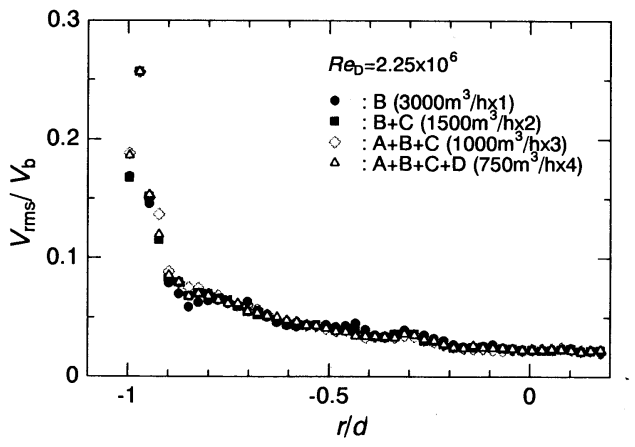

Fig.11 Turbulent intensity at test section

部における流動状態を把握するために，流速分布と乱 れ強さの分布を計測した.

本試験は，超音波流速分布計（UVP）を用いて行っ た. 超音波トランスデューサを流れに対して $30^{\circ}$ の角 度にて挿入できる配管を試験部に設置した．超音波卜 ランスデューサの基本周波数は $0.5 \mathrm{MHz}$ である. また, 本計測器には液体中に反射体が必要となるため，管内 径の 12 倍上流から微細気泡を混入した. 微細気泡の発 生にはNIKUNI M50S を使用した. 本装置により発生 するとされる平均気泡径は，およそ30um である．主 配管からポンプにて作動流体を引き出し，空気を混入 後, 再び主配管に混合された微紐気泡とともに戻すシ ステムとなっている. 空気は，ポンプのサクション側 における負圧により吸引される．混入される空気と配 管中の作動流体の流量比は約 $0.3 \%$ 目安とした. なお, このように試験部上流側にて, ポンプによる吸い出し 吸い込みを行うことによる影響は，ポンプの流量を減 じた場合，また，流量比を高くした場合においても流 速分布が変化しないことから，それがないことを確認 した. なお，測定を行った流量は $3000 \mathrm{~m}^{3} / \mathrm{h}$ ，レイノル ズ数にして $2.25 \times 10^{6}$ である.

流速分布を図 10 に示す．UVP では，測定線に沿つ た流速成分が計測されるため，半径方向流速成分は流 
れ方向成分に比して十分に小さいものとして，計測さ れた成分を $\cos 30^{\circ}$ にて除したものを使用した. 結果と して, いかなるライン選択のパターンによっても, $r / D$ が 0.5 付近（管壁から約 $200 \mathrm{~mm}$ ）まではべき乗則によ く一致し, 中心付近ではおよそフラットになるという 流速分布となっている. なお, 特に中心部付近で完全 にフラットな速度分布になっていないことについては, UVP による計測の特性上, 超音波の反射等による定在 波がこの領域に存在するような状態になり，これを打 ち消すだけ十分な信号が計測できなかったことによる 影響と考えられる.

乱れ分布について図 11 に示す. 本計測では測定体積 が比較的大きいこともあり, 特に中心部よりの乱れ強 さに関しては一般的な発達乱流からすると小さめに出 ている. しかしながら，その分布自体については，特 に異常は観測されていないと考えられる. 以上のこと から，本設備の試験部においては，旋回流や偏流のな い, 十分に発達した流れ場であるといえる.

4.3 流量変動 一般的に流量変動が流量計の校正 結果におよぼす影響については, 校正対象の流量計に 依存するところが大きく，一概に定量化はできない． しかしながら, ポンプを 4 台使用して循環運転を行う ことから, 大規模な脈動が発生する可能性があるため, 流量変動を確認した. 試験部に Krohne 社製の ALTOSONIC V 600A（WS と同型）を設置し，そのパ ルスを周波数アナライザ（横河製 DL750）により解析 した. ほぼ，瞬時の流量が計測されていると考えられ る.

代表的な流量変動の例を図 12 に示す.最大流量点近 くの約 $10000 \mathrm{~m}^{3} / \mathrm{h}$ の試験結果である. 本流量計にて計 測された流量に関してはきわめて安定しており, 計測 時間（10 分； 1 回の校正にかかる時間に相当）の間に 大規模な脈動は発生していない. 最大流量においても, ほぼ同様の結果が得られると考えられる.なお，この 結果における流量変動は標準偏差で $0.4 \%$ 程度である.

同様の試験を, 流量とライン選択を変えて行ってい る. その結果として, 流量がもつとも低い場合（750 $\mathrm{m}^{3} / \mathrm{h}$ ) では, 約 $1.2 \%$ 程度の流量変動が発生するが, そ れよりも大きい流量では $0.4 \sim 0.6 \%$ 程度と, よく安定 している. また, ライン選択のパターンごとに流量変 動の規模が大きく異なることがないことも確認できた.

4.4 プルーパー性能試験プルーバーによる流量 計の $\mathrm{K}$ ファクターは以下の式により行われる.

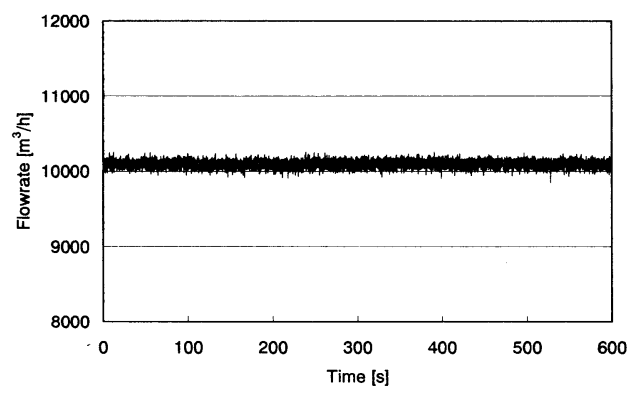

Fig.12 Trend of flowrate at test section

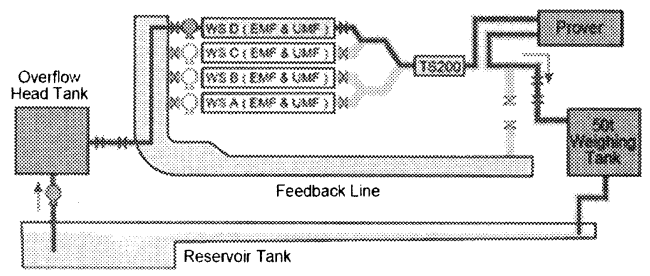

Fig.13 Schematic diagram of volume calibration

$$
K_{\mathrm{DUT}}=\frac{I_{\mathrm{DUT}}}{V S}
$$

パルス数に関する誤差はほとんどないことから, 基準 体積を正確に求めることが，プルーバーの精度を高め ることになる. プルーバーの体積は通常, 基準体積夕 ンクとの比較で行われるが, 本設備では, プルーバー と国家標準である $50 \mathrm{t}$ 秤量夕ンクを配管で結ぶ事がで きる特徵をいかすことにした. この方法で行う方が, 不確かさを減じることが可能である. しかしながら， プルーバーの基準体積は約 $2 \mathrm{~m}^{3}$ であることから, 秤量 タンクとの容量差が大きく, 直接比較することは難し い. そこで, 図 13 に示すように, トランスファースタ ンダード（図中TS200; 以下 TS）を用い，いったんこ の流量計を 50t 秤量タンクにて校正し， K ファクター $\left(K_{\mathrm{TS}}\right)$ を求める. その後, この校正された $\mathrm{K}$ ファク ターを用い，プルーバーの基準体積を逆算する手法を 採用した. 基準体積は, ほぼ設計值通りの $2 \mathrm{~m}^{3}$ が得ら れ，またこの校正により得られる体積の平均值の再現 性については 0.01\%以下であった. この基準体積の不 確かさ評価の詳細については別報(12)にて述べるが, こ

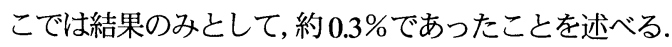
ただ，このプルーバーを用いた流量計の校正におい ては, 繰り返し性が $0.06 \sim 0.1 \%$ 若干大きくなってい る.これは, プルーバーの基準体積部の配管長さが約 $9 \mathrm{~m}$ と短く, ディタクタをたたくタイミングのばらつ きが，相対的に大きく観測されてしまうためと考えら 
れる. 今後内面コーティング状況やディタクタセンサ の調整により軽減を目指すが, 設備の不確かさ評価で は, 現状により評価している.

なお，本手法による基準体積の校正により，このプ ルーバーは流量の国家標準にトレーサブルであると言 えることを付記する,

\section{5. 結}

原子力発電所給水流量計の実流校正を行うことを主 たる目的として, 高レイノルズ数実流校正設備を開 発・構築した. 本設備は給水配管をレイノルズ数の観 点から模擬することができ, 水温 $70{ }^{\circ} \mathrm{C}$, 流量 12000 $\mathrm{m}^{3} / \mathrm{h}$ により, その最大レイノルズ数 $1.8 \times 10^{7}$ (600A 配 管の場合）を達成した. このレイノルズ数領域での実 流量校正設備は世界でも例を見ない.

設備の性能として, 被試験流量計を設置する近傍で の流速分布を計測し, 偏流や旋回流がないこと, また 十分に発達した流れであることを確認した. また流量 変動についても, 大規模な脈動等がなく, 流量計の校 正に十分な性能を持つことを確認した.

また, 本設備の流量の標準となる実用参照標準流量 計の流量に対する特性および再現性を示し, 非常に高 い精度にて流量校正が可能であることを示した. また, 実用標準流量計の温度特性について検証するためのプ ルーバーの性能試験も行い，十分な精度を持っている ことを示した.

以上のように, 高レイノルズ数における実流校正設 備が構築された. 別報 ${ }^{(12)}$ において, 設備の不確かさ評 価について報告するものとする.

\section{碀辞}

本研究は経済産業省電源特別会計によって行われた ここに謝意を記す．また，スウエーデン SP における 試験では, Dr. Anders Anderson, Dr. Krister Stoltに多大 なる尽力をいただいた．合わせて謝意を記す．

\section{文献}

(1) Power uprate for nuclear plants, Nuclear Power Plant Fact Sheets, NRC (2004)

(2) Status report on power uprates, SECY 03-0190, NRC (2003)

(3) Federal Register Notice June 1, 2000, RIN 3150-AG26 (2000)

(4) NRC Regulations 10 CFR Part50

(5) Okamoto, K., Kikura, H., NPP power uprates using ultrasonic flowmeter, J. At. Energy Soc. Japan, Vol.49, No.1 (2007), pp.39-44

(6) General Electric BWR Thermal Analysis Basis (GETAB) : Data, Correlation and Design Application, General Electric, NEDO-10958-A (1977)

(7) Performance Test Code 6 on Steam Turbine, ASME PTC 6 (1996)

(8) Guide to the Expression of Uncertainty in Measurement, ISO (1995)

(9) ISO/CD 17089 (2006) (to be published)

(10) Sato, H., et al, Proceedings of FEDSM2006, Miami, FL, (2006)

(11) Furuichi, N., et al., Proceedings of ICONE15, Nagoya, (2007)

(12) Furuichi, N., et al., Transactions of the Japan Society of Mechanical Engineers, Series $B$ (to be submitted)

(13) Terao, Y., et. al, Transactions of the Society of Instrument and Control Engineers, 36, 1 (2000) 